\title{
A CLINICAL, EPIDEMIOLOGICAL, LABORATORIAL, HISTOLOGICAL AND ULTRASONOGRAPHICAL EVALUATION OF ANTI-HCV EIA-2 POSITIVE BLOOD DONORS
}

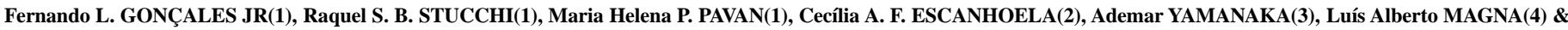 \\ Neiva S. L. GONÇALES(5)
}

\begin{abstract}
SUMMARY
Between 1992 and 1997, 790 blood donors with anti-HCV EIA-2 strongly reagent (relationship between the sample optical density/cut-off > 3) detected at the blood bank serological screening, were evaluated in ambulatory environment. They were all negative for Chagas disease, syphilis, hepatitis B (HBsAg) and AIDS. Blood samples were collected at the first ambulatorial evaluation, for hemogram, biochemical tests and new serological tests for HCV (anti-HCV EIA-2). In blood samples of 226 repeatedly reagent anti-HCV EIA-2 blood donors, supplementary "immunoblot" test for HCV (RIBA-2) was used. In 209 donors, the presence of HCVRNA was investigated by the PCR test. The abdominal ultrasonography was realized in 366 donors. In 269 patients liver biopsy was performed for the histopathological study. The follow-up of blood donors showed that $95.6 \%$ were repeatedly EIA- 2 reagent, $94 \%$ were symptomless and denied any hepatitis history, with only $2 \%$ mentioning previous jaundice. In $47 \%$ of this population at least one risk factor has been detected for the HCV transmission, the use of intravenous drugs being the main one (27.8\%). Blood transfusion was the second factor for HCV transmission (27.2\%). Hepatomegaly was detected in $54 \%$ of the cases. Splenomegaly and signs of portal hypertension have seldom been found in the physical examination, indicating a low degree of hepatic compromising in HCV. Abdominal ultrasound showed alterations in $65 \%$ of the subjects, being the steatosis the most frequent (50\%). In $83.5 \%$ of the donors submitted to the liver biopsy, the histopathological exam showed the presence of chronic hepatitis, usually classified as active (89\%) with mild or moderate grade in most of the cases (99.5\%). The histopathological exam of the liver was normal in $1.5 \%$ of blood donors. The RIBA-2 test and the HCV-RNA investigation by PCR were positive in respectively 91.6 and $75 \%$ of the anti-HCV EIA2 reagent donors. The HCV-RNA research was positive in $82 \%$ of the RIBA-2 positive subjects, in $37.5 \%$ of the indeterminate RIBA2 donors and in $9 \%$ of the negative RIBA-2 donors. Chronic hepatitis has also been observed in $50 \%$ of the histopathological exams of the anti-HCV EIA-2 reagent donors which were indeterminate RIBA-2. Among 18 blood donors with minimal changes histopathological exam $11(61 \%)$ were HCV-RNA positive. Our blood donors anti-HCV reagent generally had clinical, laboratorial and histopathological features observed in patients with chronic HCV hepatitis and a high proportion could be identified in interviews and medical evaluation realized in blood blanks. Generally, these HCV infected donors are identified and discharged only by the serological tests results.
\end{abstract}

KEYWORDS: Anti-HCV; Blood donors; Viral Hepatitis; Hepatitis C; Brazil

\section{INTRODUCTION}

Since the cloning and characterization of hepatitis $\mathrm{C}$ virus $(\mathrm{HCV})^{7}$, several studies have confirmed that $\mathrm{HCV}$ is the principal agent of posttransfusional hepatitis around the world ${ }^{9,14,18}$. Blood transfusions, the use of illicit drugs or, more rarely, organ transplants are the most common pathways of $\mathrm{HCV}$ transmission ${ }^{5}$. About $18 \%$ to $26 \%$ of the patients with $\mathrm{HCV}$ develop jaundice during the acute phase of the infection ${ }^{10}$. In the remaining cases, the patients show no symptoms ${ }^{12}$. About $85 \%$ of individuals with $\mathrm{HCV}$ become chronically infected ${ }^{1,12}$ and the evolution to chronic hepatitis $(\mathrm{CH})$ usually passes imperceived ${ }^{12}$. Approximately
$70 \%$ of the patients chronically infected with HCV have a persistent elevation of hepatic enzymes ${ }^{1}$ and liver biopsies generally show histological evidence of mild $\mathrm{CH}^{8,17,22,23}$. The routine screening of blood donors has led to the identification of individuals with anti-HCV antibodies who are asymptomatic and have no history of liver disease or of exposure to risk factors for viral hepatitis. However, the clinical significance of anti-HCV antibodies in these otherwise healthy persons is unclear ${ }^{23}$. In this study, we investigated the laboratorial, ultrassonographic, histological and epidemiological alterations in anti$\mathrm{HCV}$ blood donors and attempted to correlate these with the progress of the infection.

(1) Disciplina de Doenças Transmissíveis da Faculdade de Ciências Médicas-UNICAMP, Campinas, São Paulo, Brasil.

(2) Departamento de Anatomia Patológica da Faculdade de Ciências Médicas-UNICAMP, Campinas, São Paulo, Brasil

(3) Centro de Diagnóstico de Doenças do Aparelho Digestivo-Gastrocentro-UNICAMP, Campinas, São Paulo, Brasil.

(4) Departamento de Genética Médica da Faculdade de Ciências Médicas-UNICAMP, Campinas, São Paulo, Brasil.

(5) Hemocentro-Campinas-UNICAMP, Campinas, São Paulo, Brasil.

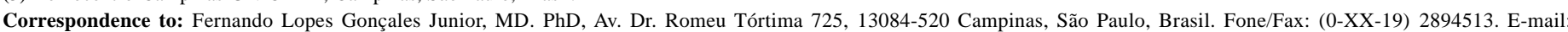
flopes@correionet.com.br 


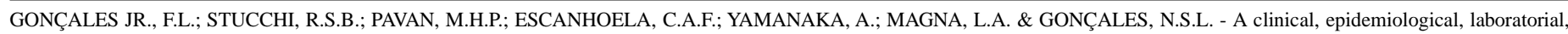
histological and ultrasonographical evaluation of anti-HCV EIA-2 positive blood donors. Rev. Inst. Med. trop. S. Paulo, 42(3):147-152, 2000.

\section{MATERIALS AND METHODS}

Seven hundred and ninety consecutive blood donors attending the Hemocenter at Unicamp, Campinas, SP State, Brazil, between April 1992 and December 1997 who were positive at least twice in the anti-HCV EIA-2 test were referred to the Study Group of the Viral Hepatitis in the Discipline of Transmissible Diseases of Faculty of Medical Sciences, Unicamp. All donors had an EIA-2 ratio >3 (expressed as the optical density of the test sample divided by the cutoff value). The result was considered a low positive when the EIA ratio was $<3$ and a high positive when the ratio was $>3$. All donors were negative for Chagas disease, syphilis and AIDS. Individuals who were HBsAg positive were excluded. Of the 790 blood donors, 699 (88\%) were men and 91 (12\%) women with ages ranging from 18 to 60 years old (mean of 33 years). Most $(709,90 \%)$ were white and the remaining $(81,10 \%)$, black. The donors were interviewed using a standard questionnaire designed to identify a series of parameters, including known risk factors for $\mathrm{HCV}$ infection such as previous blood transfusion, intravenous drug use (IVDU), acupuncture, tattoos, sexual or social contacts with icteric persons, the presence of symptoms related to viral hepatitis, jaundice and sexual habits. All donors underwent a complete physical examination. At the first clinical evaluation, all donors were retested using the anti-HCV EIA-2 assay (2nd. generation HCV EIA, Abbott Laboratories, North Chicago, IL). Hemograms and hepatic biochemical determinations (ALT and AST dosages and protein electrophoresis) were done four times a year. Only donors with an EIA-2 ratio $>3$ continued in the follow-up. HBV markers were also retested in 582 anti-HCV EIA-2 positive blood donors at the first clinical evaluation with commercial kits: HBsAg (AUSZYME MONOCLONAL, Abbott), anti-HBcAg (CORZYME, Abbott) and anti-HBsAg (AUSAB, Abbott). ALT activity was determined in serum by an automated assay (COBAS-MIRA, ROCHE) and the normal values were $0-40 \mathrm{UI} / 1$. The results were expressed as the ALT quotient (qALT), calculated dividing the ALT level in the sample by the maximum normal value for the method. When the ALT value was elevated, qALT was always >1 RIBA II (4 antigens, ORTHO Diagnostics Systems, Raritan, N.J.) were conducted in 226 donors. The result was considered positive when the samples reacted with two or more proteins of the kit, indeterminate when there was a reaction with only one of the proteins and negative when there was no reaction with any protein. Two hundred and nine donors were screened for HCV RNA by PCR (HCVAMPLICOR, ROCHE). Abdominal ultrasound (US) was performed in 366 anti-HCV EIA-2 positive blood donors and the diagnoses were chronic hepatitis, steatosis, hepatomegaly, hepato and splenomegaly, liver cirrhosis or normal liver. All donors 269 with a qALT $>1$ or with hepatomegaly in the physical examination underwent a liver biopsy. The diagnoses were normal liver (NL), chronic persistent hepatitis (CPH), chronic active hepatitis (CAH), chronic lobular hepatitis (CLH), minimal changes (MC), liver cirrhosis (LC) or other non-related lesions. Chronic active hepatitis was mild, moderate or intense according periportal activity. Statistical comparisons used the $\mathrm{X}^{2}$ or Fisher's exact tests to compare differences among groups. A $\mathrm{p}$ value $\leq 0.05$ was considered significant.

\section{RESULTS}

Anti-HCV EIA-2 prevalence. Seven hundred and fifty six patients (95.6\%) were anti-HCV EIA-2 positive, 17 (2.2\%) were negative and $17(2.2 \%)$ were anti-HCV indeterminate.
Epidemiological evaluation. One hundred and twenty two (16\%) anti-HCV positive donors reported previous social or sexual contact with persons having viral hepatitis. Alcohol abuse was reported by $302 / 756$ (40\%) donors. HCV RNA was detected in 66/88 (75\%) blood donors who drank alcohol daily tested and in 92/125 (74\%) non-alcohol drinkers ( $p>0.05$ ). Of the 756 anti-HCV blood donors evaluated, $352(47 \%)$ had at least one risk factor for HCV infection: 98/352 (27.8\%) were IVDU, $96 / 352(27.2 \%)$ had transfusions, 7/352 (2\%) had homosexual contacts; $9 / 352(2.6 \%)$ had received treatment with acupuncture, 62/352 (17.7\%) had tattoos and 80/352 (22.7\%) had more than one risk factor. Among the 209 blood donors tested for HCV RNA, 25/32 (78\%) with tattoos were HCV RNA-positive and 132/177 (74\%) donors without tattoos were HCV RNA-positive by PCR ( $>>0.05)$. Among the 31 patients with tattoos all (100\%) were RIBA-2 positive. In 195 blood donors without tattoos, $176(90.2 \%)$ were positive to RIBA-2, 9 (4.6\%) were negative and $10(5.2 \%)$ were RIBA-2 indeterminate ( $p>0.05$, Fisher test).

Clinical evaluation. Of 756 anti-HCV positive blood donors, 709 (94\%) had no symptoms and $47(6 \%)$ had at least one symptom associated with hepatic disease. Only $15(2 \%)$ donors reported previous jaundice and $406(54 \%)$ had hepatomegaly. Splenomegaly was observed in 36/ $756(5 \%)$ donors. HCV RNA was detected in 56/77 (72\%) donors without hepatomegaly, in 44/68 (64\%) with mild hepatomegaly $(0-3 \mathrm{~cm})$ and in $57 / 64(89 \%)$ with moderate or intense hepatomegaly $(>3 \mathrm{~cm})$. There was a significant correlation between hepatomegaly at clinical evaluation (liver $>3 \mathrm{~cm}$ ) and HCV RNA positivity. Of 256 donors who underwent to liver biopsies, chronic hepatitis was present in 85/99 (86\%) donors without hepatomegaly, in 62/83 (82\%) with mild hepatomegaly and in $59 / 74(80 \%)$ with intense hepatomegaly $(\mathrm{p}>0.05)$. Portal hypertension or hepatic insufficiency was present in $3 / 756(0.4 \%)$ donors.

Abdominal ultrasound (US). Two hundred and thirty seven of 366 $(65 \%)$ donors had at least one alteration upon US. Steatosis was noted in $118(50 \%), \mathrm{CH}$ in $33(14 \%)$, hepatomegaly or hepatosplenomegaly in $79(33 \%)$ and LC in $7(3 \%)$ of the 237.

Liver biopsy. Two hundred and sixty nine anti-HCV positive donors underwent to liver biopsy. A normal liver was diagnosed in $4(1.5 \%)$, chronic hepatitis in $225(83.5 \%)$, steatosis in $9(3 \%)$, liver cirrhosis in 6 (2\%), minimal changes in $23(9 \%)$ and other non-related diagnoses in 2 (1\%). Of 225 donors with $\mathrm{CH}, 200(89 \%)$ had CAH which was mild or moderate in $199(99.5 \%)$ and intense in $1(0.5 \%)$ patient. $\mathrm{CPH}$ was diagnosed in 23/225 (10\%) of donors and 2/225 (1\%) had CLH.

Table 1 shows that $85.2 \%$ of the donors diagnosed with $\mathrm{CH}$ by abdominal ultrasound had chronic hepatitis upon histological examination. There was a strong correlation between steatosis diagnosed by US and $\mathrm{CH}$ determined by histology. About $86 \%$ of the donors with a normal US had $\mathrm{CH}$ upon histological examination. There was no significant correlation between the US results and chronic hepatitis diagnosed histologically.

Laboratorial evaluation. Protein electrophoresis showed that 654/ $696(94 \%)$ anti-HCV positive donors had normal albumin levels and 42/ 696 (6\%) had hypoalbuminemia. $\mathrm{CH}$ was observed in 16/23 (69.5\%) donors with hypoalbuminemia who underwent liver biopsy. All donors with hypoalbuminemia had an altered liver histology. There was a significant positive correlation between hypoalbuminemia and $\mathrm{CH}$ 


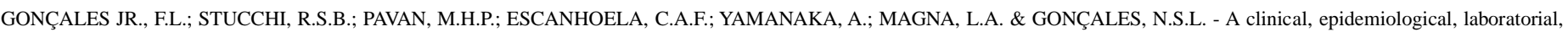
histological and ultrasonographical evaluation of anti-HCV EIA-2 positive blood donors. Rev. Inst. Med. trop. S. Paulo, 42(3):147-152, 2000.

Table 1

US abdominal alterations and histologic diagnoses in anti-HCV positive blood donors $(\mathrm{n}=218)$

\begin{tabular}{|c|c|c|c|c|c|c|c|c|c|c|c|c|c|c|}
\hline \multicolumn{15}{|c|}{ LIVER HISTOLOGY } \\
\hline \multirow[b]{2}{*}{ ULTRASOUND } & \multicolumn{2}{|c|}{$\begin{array}{l}\text { Chronic } \\
\text { hepatitis }\end{array}$} & \multicolumn{2}{|c|}{ Steatosis } & \multicolumn{2}{|c|}{$\begin{array}{c}\text { Liver } \\
\text { Cirrhosis }\end{array}$} & \multicolumn{2}{|c|}{$\begin{array}{c}\text { Normal } \\
\text { liver }\end{array}$} & \multicolumn{2}{|c|}{$\begin{array}{l}\text { Minimal } \\
\text { changes }\end{array}$} & \multicolumn{2}{|c|}{ Others } & \multicolumn{2}{|c|}{ Total } \\
\hline & $\mathrm{n}$ & $(\%)$ & $\mathrm{n}$ & $(\%)$ & $\mathrm{n}$ & $(\%)$ & $\mathrm{n}$ & $(\%)$ & $\mathrm{n}$ & $(\%)$ & $\mathrm{n}$ & $(\%)$ & $\mathrm{n}$ & $(\%)$ \\
\hline Chronic hepatitis & 23 & 85.2 & 1 & 3.7 & 1 & 3.7 & 1 & 3.7 & 1 & 3.7 & - & - & 27 & 100 \\
\hline Steatosis & 85 & 86.7 & 1 & 1.0 & - & - & - & - & 12 & 12.3 & - & - & 98 & 100 \\
\hline Liver cirrhosis & 6 & 85.7 & - & - & - & - & - & - & 1 & 14.3 & - & - & 07 & 100 \\
\hline Normal & 38 & 86.4 & 3 & 6.8 & 1 & 2.2 & - & - & 2 & 4.6 & - & - & 44 & 100 \\
\hline Hepatomegaly & 19 & 73.0 & 1 & 3.8 & - & - & - & - & 4 & 15.6 & 2 & 7.6 & 26 & 100 \\
\hline Splenomegaly & 11 & 68.8 & 2 & 12.5 & - & - & 1 & 6.2 & 2 & 12.5 & - & - & 16 & 100 \\
\hline Total & 182 & 83.5 & 8 & 3.6 & 2 & 0.9 & 2 & 0.9 & 22 & 10.2 & 2 & 0.9 & 218 & 100 \\
\hline
\end{tabular}

Table 2

RIBA-2 and HCV RNA results for anti-HCV positive blood donors based on the histological diagnosis ( $\mathrm{n}=159)$.

\begin{tabular}{|c|c|c|c|c|c|c|c|c|c|c|}
\hline \multicolumn{11}{|c|}{ HISTOLOGICAL DIAGNOSIS } \\
\hline \multirow{2}{*}{$\begin{array}{l}\text { LABORATORIAL } \\
\text { TESTS }\end{array}$} & \multicolumn{2}{|c|}{ Chronic Hepatitis } & \multicolumn{2}{|c|}{ Steatosis } & \multicolumn{2}{|c|}{ Liver Cirrhosis } & \multicolumn{2}{|c|}{ Minimal changes } & \multicolumn{2}{|c|}{ Others } \\
\hline & $\mathrm{n}$ & $\%$ & $\mathrm{n}$ & $\%$ & $\mathrm{n}$ & $\%$ & $\mathrm{n}$ & $\%$ & $\mathrm{n}$ & $\%$ \\
\hline $\begin{array}{l}\text { RIBA-2 } \\
\text { Positive }\end{array}$ & & & & & & & & & & 06 \\
\hline Negative & - & - & - & - & - & - & $1 / 1$ & $\begin{array}{c}0.0 \\
100.0\end{array}$ & - & - \\
\hline Indeterminate & $3 / 6$ & 50.0 & - & - & - & - & $3 / 6$ & 50.0 & - & - \\
\hline \multicolumn{11}{|l|}{ HCV-RNA } \\
\hline Positive & $118 / 135$ & 87.4 & $3 / 135$ & 2.2 & $2 / 135$ & 1.5 & $11 / 135$ & 8.1 & $1 / 35$ & 0.8 \\
\hline Negative & $16 / 24$ & 66.7 & $1 / 24$ & 4.1 & - & - & $7 / 24$ & 29.2 & - & - \\
\hline
\end{tabular}

determined histologically ( $\mathrm{p}<0.05)$. Hypergammaglobulinemia was seen in 256/642 (40\%) anti-HCV positive donors. Of 131 blood donors who underwent liver biopsy, $118(90 \%)$ with hypergammaglobulinemia had chronic hepatitis while $88 / 114(77 \%)$ donors with normal levels of gammaglobulins had chronic hepatitis based on histology. There was a significant positive correlation between gammaglobulin levels and $\mathrm{CH}$ determined histologically $(\mathrm{p}<0.05)$.

Of the 756 anti-HCV positive blood donors, $562(74.4 \%)$ had a qALT $>1$ and $194(25.6 \%)$ a qALT $\leq 1$. Liver biopsies were done on 269 of these 756 donors, 257 (95.5\%) of whom had qALT $>1$ and $12(4.5 \%)$ a qALT $\leq 1$. A total of $221 / 257(86 \%)$ donors with qALT $>1$ had chronic hepatitis as did in $4 / 12(33.4 \%)$ donors with a qALT $\leq 1$. There was a significant positive correlation between ALT activity and chronic hepatitis $(\mathrm{p}<0.05)$.

RIBA-2 and HCV RNA. A total of 226 anti-HCV positive donors were tested for RIBA-2. Of these $207(91.6 \%)$ were RIBA-2 positive, $10(4.4 \%)$ were negative and $9(4 \%)$ were indeterminate. Of 209 antiHCV positive donors tested for HCV-RNA by PCR, 157 (75\%) were HCV RNA-positive and 52 (25\%) were negative.

Table 2 shows the RIBA-2 and HCV RNA results in 159 anti-HCV positive blood donors who underwent a liver biopsy. One hundred and thirty four out of 152 (88\%) RIBA-2 positive donors had $\mathrm{CH}$ and 12/
$152(8 \%)$ had MC. 4/152 (2.8\%) had steatosis, $1 / 152(0.6 \%)$ had $\mathrm{CH}$ and $1 / 152(0.6 \%)$ had other diagnoses. One RIBA-2 negative donor had $\mathrm{MC}$ and in six RIBA-2 indeterminate donors $3(50 \%)$ had $\mathrm{CH}$ and 3 (50\%) had MC. In addition 118/135 (87.4\%) PCR-positive donors had $\mathrm{CH}$ while $16 / 24(66.7 \%)$ cases of $\mathrm{CH}$ were noted among HCV RNAnegative donors. There was a significant positive correlation between the presence of HCV RNA in serum and chronic hepatitis upon histological examination $(\mathrm{p}<0.05)$.

Among anti-HCV positive donors with a qALT>1, $196(95.6 \%)$ were RIBA-2 positive, $8(3.9 \%)$ were RIBA-2 indeterminate and $1(0.5 \%)$ was RIBA-2 negative. Among 21 donors with a qALT $\leq 1,11(52.4 \%)$ were RIBA-2 positive, $2(9.5 \%)$ were RIBA-2 indeterminate and 8 (38.1\%) were RIBA-2 negative. There was a significant positive correlation between ALT levels and the results of the RIBA-2 assay $(\mathrm{p}<0.05)$. Among 185 anti-HCV positive donors with a qALT $>1,152$ (82\%) were HCV RNA-positive and 33 (18\%) negative, while among 24 anti-HCV positive donors with a qALT $\leq 1,5$ (21\%) were HCV RNApositive and $19(79 \%)$ were negative. There was a significant positive correlation between ALT levels and occurrence of HCV-RNA by PCR.

A total of 192 anti-HCV EIA-2 positive donors were tested for RIBA and HCV RNA by PCR (Table 3). Among 173 RIBA-2 positive donors, $142(82 \%)$ were HCV RNA-positive and 31 (18\%) were negative. Among 11 RIBA-2 negative donors, 1 (9\%) was HCV RNA-positive and 10 


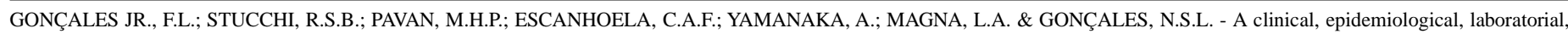
histological and ultrasonographical evaluation of anti-HCV EIA-2 positive blood donors. Rev. Inst. Med. trop. S. Paulo, 42(3): 147-152, 2000.

(91\%) were HCV RNA-negative. Among 8 RIBA-2 indeterminate blood donors, $3(37.5 \%)$ were HCV RNA-positive and $5(62.5 \%)$ were negative. There was a significant positive correlation between RIBA-2 and the PCR results $(\mathrm{p}<0.05)$.

Table 3

RIBA-2 and HCV-RNA results in anti-HCVpositive blood donors $(\mathrm{n}=192)$

\begin{tabular}{lcccccc}
\hline & \multicolumn{4}{c}{ HCV-RNA (PCR) } & \multicolumn{2}{c}{ Total } \\
RIBA-2 & Positive & \multicolumn{2}{c}{ Negative } & \multicolumn{2}{c}{ n } & $(\%)$ \\
\hline Positive & 142 & 82.0 & 31 & 18.0 & 173 & 100.0 \\
Negative & 1 & 9.0 & 10 & 91.0 & 11 & 100.0 \\
Indeterminate & 3 & 37.5 & 5 & 62.5 & 8 & 100.0 \\
Total & 146 & 76.0 & 46 & 24.0 & 192 & 100.0 \\
\hline
\end{tabular}

A total of 582 anti-HCV positive blood donors were tested for HVB markers. Of these, 58 (10\%) were $\mathrm{HBsAg}$ negative/anti-HBc total positive/anti-HBs negative, $86(15 \%)$ were $\mathrm{HBsAg}$ negative/anti-HBc total positive/anti-HBs positive and 23 (4\%) were positive only for antiHBs, $415(71 \%)$ were negative for all HBV markers

Donors with chronic hepatitis $(\mathbf{C H})$. Among 225 patients with chronic hepatitis, $18(8 \%)$ had symptoms of hepatitis, $8(4 \%)$ had previous jaundice and $179(80 \%)$ denied any contact with icteric persons. Upon clinical examination, $127(56 \%)$ had hepatomegaly. The spleen was enlarged in $17 / 225(8 \%)$ cases. Clinical signs of portal hypertension were detected in $3 / 225(1 \%)$ patients. Hypoalbuminemia was detected in $16(7 \%)$ patients and $118(52.4 \%)$ patients had elevated levels of gammaglobulins. Abdominal US done in 182 patients diagnosed $\mathrm{CH}$ in $23(13 \%)$ and steatosis in 85/182 (47\%) (eight cases of steatosis were also diagnosed among the 23 patients with $\mathrm{CH}$ ). Thus steatosis was present in 93/182 (51\%) blood donors with chronic hepatitis detected by US. Cirrhosis was detected by US in 6/182 (3\%) cases while 38/182 (21\%) had a normal US. Thirty individuals (16\%) showed only enlargement of the liver or spleen. Of 134 patients with $\mathrm{CH}$ who were screened for HCV RNA, 118 (88\%) were HCV RNA-positive whereas among 137 patients with $\mathrm{CH}$ tested for RIBA-2, 134 (98\%) were positive and $3(2 \%)$ were indeterminate. In the three patients with $\mathrm{CH}$ who were RIBA-2 indeterminate, only antibody anti-c22-3 was detected. Both RIBA-2 and HCV-RNA screening were done in 124 patients with $\mathrm{CH}$. Of these 108 (89\%) RIBA-2 positive patients were HCV RNA-positive while among three RIBA-2 indeterminate patients $2(66.6 \%)$ were $\mathrm{HCV}$ RNA-positive and 1 (33.3\%) was HCV RNA-negative.

Among 18 blood donors with minimal changes who were screened for HCV-RNA $11(61 \%)$ were positive and 7 (39\%)were negative. Among 16 tested for RIBA-2, 12 (75\%) were positive, 3 (19\%) were indeterminate and $1(16 \%)$ was negative.

\section{DISCUSSION}

Among our donors, 95.6\% were anti-HCV positive at the second EIA test and $91.6 \%$ were RIBA-2 positive. Even with the improvement in the sensitivity of second generation tests (anti-HCV EIA-2), falsepositives (negative RIBA-2) are claimed, in other series, to still occur in $40 \%$ of the donors tested by EIA $(15,85)$. The low number of false- positive cases among our donors perhaps reflects the fact that we only evaluated anti-HCV in individuals with an EIA-2 ratio $>3$ (highly positive). At least one risk factor for $\mathrm{HCV}$ was detected in $47 \%$ of the donors. Blood transfusion and drug abuse were the principal risk factors for the acquisition of HVC. The use of drugs is frequently denied by blood donors $^{8}$. In one study of RIBA positive blood donors, who denied the use of IV drugs in their initial interview at a blood bank, subsequently $42 \%$ admitted this practice in the past when interviewed a second time $e^{2,8}$. In some cases, previous use of drugs is not considered as risk factor for the future transmission of HCV. The intravenous use of tonics, containing glucose and vitamins, is widely spread in Brazil, including among some sportsmen. As these substances are not considered drugs, they are not reported in the blood banks interviews. A small number of donors (2\%) admitted having a homosexual relationship. Among the $96 \%$ of donors who reported heterosexual behavior, $16 \%$ had multiple partners. In fact, the interviews at blood banks generally exclude donors with risky sexual behavior more easily than IVDU.

Some authors had reported no association between previous treatment with acupuncture or tattooing and an increase in $\mathrm{HCV}$ transmission ${ }^{8}$. Only $3 \%$ of our donors had undergone acupuncture and $18 \%$ had tattoos. Tattooing was not associate with a greater frequency of viremia $(p>0.05)$ or greater positivity in the RIBA test, but was associated with more frequent drug addiction. Alcohol abusers with chronic hepatopathies have a high positivity for anti-HCV with $65 \%-94 \%$ showing HCV RNA ${ }^{21}$. We also detected $75 \%$ of our donors who were alcohol abusers were positive for HCV RNA, which also happened in $74 \%$ of the non-alcoholists.

There was a significant correlation between intense hepatomegaly at physical examination and greater positivity for HCV RNA in the serum of our donors. However, there was no association between hepatomegaly and chronic hepatitis upon the histological examination. For this reason, hepatomegaly was not considered indicative of the need for liver biopsies among anti-HCV positive donors.

Steatosis is a histological marker for chronic hepatitis caused by HCV and when observed at US of anti-HCV positive donors with an EIA ratio >3 may be indicative of that disease. Although US diagnosed only $14 \%$ of our donors as having chronic hepatitis, all of them were viremic. In most cases, the diagnosis of $\mathrm{CH}$ by US agreed with the histological results $(85.2 \%$ of donors) (Table1). Only 3.7\% of the donors with US suggesting $\mathrm{CH}$ had a normal histological result. The presence of normal liver in US was not correlated with histological findings because about $86 \%$ of these donors showed $\mathrm{CH}$ upon histology. In some situations, US provided additional information which allowed a better clinical evaluation of these donors.

Histological examination revealed light or moderate chronic hepatitis in most donors $(83.5 \%)$ with a few individuals who were histologically normal $(1.5 \%)$ or had hepatic cirrhosis $(2 \%)$. This confirmed the need of a hepatic biopsy in these anti-HCV positive donors. Other reports have shown that HCV RNA-positive donors always have chronic hepatitis, with the lesions being light or moderate in $87 \%$ of the cases and intense in $13 \%^{2}$. Among the HCV RNA positive donors evaluated here, $89 \%$ had $\mathrm{CH}$ or cirrhosis, $2.2 \%$ had steatosis, $8 \%$ showed minimal changes and $0.8 \%$ had portal fibrosis (Table 2). In agreement with others studies $^{2}$, no HCV RNA positive donor had a normal histological result. Among our donors HCV RNA positivity was a predictive factor for chronic hepatitis upon histological examination. 


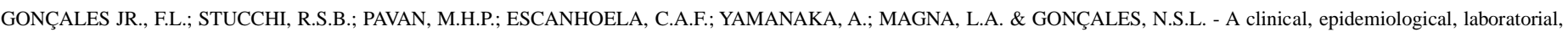
histological and ultrasonographical evaluation of anti-HCV EIA-2 positive blood donors. Rev. Inst. Med. trop. S. Paulo, 42(3):147-152, 2000.

The median age of our donors was 33.7 years old. A high frequency of advanced histological lesions was not expected since these usually appear after 20-30 years of HCV infection ${ }^{2}$. This is also applied to the hypoalbuminemia. Only $6 \%$ of donors showed hypoalbuminemia and of these, $70 \%$ had histologic diagnosis of $\mathrm{CH}(\mathrm{p}<0.05)$. In $40 \%$ of the donors was observed hypergammaglobulinemia resulted from alterations caused by HCV and not from cirrhosis, considering the mild hepatic involvement observed here. There was a significant positive correlation between hypoalbuminemia or hypergammaglobulinemia and the frequency of $\mathrm{CH}$ in the histological sections of the donors.

In our study, $91.6 \%$ of the anti-HCV positive donors were also RIBA-2 positive. This proportion is greater than the $36 \%$ of RIBA-2 positive cases reported in similar individuals in studies conducted in Italy ${ }^{16,19}$ and France ${ }^{22}$ and the $39 \%$ observed in the USA ${ }^{13}$. In Spain, $33-63 \%$ of anti-HCV positive donors were also RIBA-2 positive ${ }^{17,20}$. The discrepancy between our results and these cited above may be related to the type of donor included in our avaliation (EIA ratio >3). Of the anti-HCV donors tested, $75 \%$ were $\mathrm{HCV}$ RNA positive. In Italy, in the USA and in Spain the frequency of HCV RNA positivity was $66 \%, 58 \%$ and $63 \%$, respectively, among RIBA-2 positive and indeterminate donors ${ }^{13,16,20}$. In a recent compilation ${ }^{15} 62 \%$ of RIBA-2 positive or indeterminate donors were HCV RNA positive, a frequency slightly lower than that observed here among our donors (75\%) with an EIA ratio $>3$ and high positivity for RIBA-2.

About $74 \%$ of our donors had elevated ALT levels. Other authors, have observed that $69 \%$ of RIBA-2 positive donors have increased serum ALT levels ${ }^{8}$. Considering the anti-HCV positive donors with a qALT $>1$, 95.6\% were RIBA-2 positive compared to $52.4 \%$ of RIBA-2 positive donors with a qALT $<1(\mathrm{p}<0.05)$. Based on the histological results, a liver biopsy was always recommended in anti-HCV positive donors with an EIA ratio >3, independent of the results of confirmatory exams. Among RIBA-2 indeterminate donors who underwent a liver biopsy, $50 \%$ had a histological diagnosis of chronic hepatitis and $50 \%$ showed a liver with minimal changes. In a recent study, RIBA-2 indeterminate donors were reported to be indeterminate or positive when tested by RIBA-3 and that $30 \%$ were positive for $\mathrm{HCV} \mathrm{RNA}^{11}$. For this reason, we considered as obligatory to screen RIBA indeterminate patients for HCV RNA.

HCV RNA levels are generally lower in patients with normal values of $\mathrm{ALT}^{6}$ and this could explain the low detection of viral RNA among our donors with a normal ALT $(21 \%)$. On the other hand, HCV RNA was detected in $82 \%$ of anti-HCV positive donors with a qALT $>1$. The HCV RNA negativity in $18 \%$ of the donors with a high qALT can reflect the absence of the virus, inherent problems with the test or an increase in ALT attributable to non-viral causes.

The frequency of viremia among 192 anti-HCV positive donors screened for RIBA and PCR was $76 \%$ (146/192) with 19\% (36) having only antibodies against HCV (RIBA-2 positive or indeterminate) indicating probably cured cases of $\mathrm{HCV}$. The frequency of false-positives for HCV (RIBA-2 and HCV RNA-negative) was 5.2\% (10/192) (Table 3). False negatives for HCV RNA generally occur in patients with viral loads below the limit of detection of the PCR assay used ${ }^{25}$ or following the occurrence of intermittent viremias ${ }^{18}$. The potentially infective nature of all RIBA-2 positive donors with a negative PCR should be borne in mind. Our frequency of $14 \%$ (31/192) for RIBA positive and PCR negative patients was similar to that reported by others ${ }^{4}$, who noted that patients infected by
$\mathrm{HCV}$ recovered from the acute infection, eradicated the virus spontaneously and remained HCV RNA negative for several years ${ }^{1}$.

Eighty nine percent of the HCV RNA positive donors had hepatic lesions associated with a chronic HCV infection (87.5\% had a histological diagnosis of chronic hepatitis and $1.5 \%$ had hepatic cirrhosis) (Table 2). The remaining $11 \%$ were patients with minimal changes, perhaps because they were cases of initial chronic hepatitis C. On the other hand, $67 \%$ of HCV RNA negative donors showed chronic hepatitis upon histological examination (Table 2).

Close to one third (29\%) of the anti-HCV positive donors were positive for at least one marker of a past infection for hepatitis B virus. $\mathrm{HBV}$ and $\mathrm{HCV}$ are thought to attack these populations sequentially or simultaneously ${ }^{3,10}$.

Most donors with a histological diagnosis of chronic hepatitis were symptomless (92\%) and only $4 \%$ reported past jaundice. This pattern is characteristic of this infection. In patients with a post-transfusional HCV infection, jaundice has been detected in $19 \%-26 \%$ of the patients in the acute phase $\mathrm{e}^{10,24}$. Besides the few symptoms, donors with chronic hepatitis usually show mild hepatomegaly with a few cases of intense hepatomegaly $(7 \%)$ or splenomegaly $(8 \%)$; only $1 \%$ show signs of portal hypertension or hepatic insufficiency. Hypoalbuminemia was detected in only $7 \%$ our patients and reflected the mildly compromised function hepatic present in these still young donors with HCV. US detected chronic hepatitis in $13 \%$ of the patients with the above histological diagnosis, but diagnosed steatosis in $47 \%$ of patients with $\mathrm{CH}$ based on histological examination. Since steatosis is an etiologic marker of chronic HCV, US identified, directly or indirectly, about $60 \%$ of individuals that could have chronic hepatitis. For this reason we stipulated that anti-HCV positive donors with US results showing hepatic steatosis, should undergo a liver biopsy, to confirm chronic hepatitis. For individuals with histologic results showing minimal changes, $87 \%$ had increased serum ALT levels, $61 \%$ were positive for HCV RNA, $75 \%$ were positive for RIBA-2 and $19 \%$ were RIBA-2 indeterminate. In these cases, a complete laboratorial investigation is needed to diagnose the HCV infection.

Finally, we consider that the clinical, epidemiological, laboratorial, histological and ultrasonographical features observed among our blood donors anti-HCV EIA-2 reagent with EIA ratio $>3$ are very similar and representative of the observed among patients with chronic hepatitis $\mathrm{C}$ histologically confirmed. A high proportion of these donors could be identified in interviews and medical evaluation performed in the medical screening of the blood blanks, because they had clinical and epidemiological evidences for HCV infection. Generally, these HCV infected donors are identified and discharged only by the serological tests results, showing that the medical procedures realized in routine of blood banks are inadequate.

\section{RESUMO}

\section{Avaliação clínica, epidemiológica, laboratorial, histológica e ultrassonográfica de doadores de sangue anti-HCV EIA-2 positivos}

Entre 1992 e 1997 foram avaliados, ambulatorialmente, 790 doadores de sangue com teste anti-HCV EIA-2 fortemente reagente (relação entre 
GONÇALES JR., F.L.; STUCCHI, R.S.B.; PAVAN, M.H.P.; ESCANHOELA, C.A.F.; YAMANAKA, A.; MAGNA, L.A. \& GONÇALES, N.S.L. - A clinical, epidemiological, laboratorial, histological and ultrasonographical evaluation of anti-HCV EIA-2 positive blood donors. Rev. Inst. Med. trop. S. Paulo, 42(3):147-152, 2000.

a densidade ótica da amostra / "cut-off" > 3), que haviam sido detectados na triagem sorológica do banco de sangue. Todos eram negativos para doença de Chagas, sífilis, hepatite B (HBsAg) e AIDS. Amostras de sangue foram coletadas, na primeira consulta ambulatorial, para a realização de hemograma, exames bioquímicos e novos testes sorológicos para a HVC (anti-HCV EIA-2). Em 226 doadores anti-HCV EIA-2 repetidamente reagentes, realizou-se o teste suplementar de "immunoblot" para a HVC (RIBA-2). Em 209 doadores, pesquisou-se a presença do RNA do VHC pelo teste do PCR, através de exame automatizado (HCV-AMPLICOR, ROCHE). A ultra-sonografia abdominal foi realizada em 366 doadores e a biópsia hepática em 269 concordantes.

Notou-se que 95,6\% eram EIA-2 repetidamente reagentes, 94\% eram assintomáticos e que apenas $2 \%$ referiram icterícia pregressa. Em $47 \%$ detectou-se, pelo menos, um fator de risco para a transmissão do VHC, sendo o uso de drogas E.V. o principal deles (27,8\%). A transfusão de sangue foi o segundo fator na transmissão da $\operatorname{HVC}(27,2 \%)$. Hepatomegalia foi encontrada em 54\%. Esplenomegalia e sinais de hipertensão portal foram raramente encontrados no exame físico, denotando o baixo grau de comprometimento hepático na HVC. A ultrasonografia abdominal mostrou-se alterada em $65 \%$ dos indivíduos, sendo a esteatose a alteração mais freqüentemente observada (50\%).

Em 83,5\% dos doadores submetidos à biópsia hepática, diagnosticouse hepatite crônica, geralmente classificada como ativa (89\%) e de grau leve ou moderado na maioria dos casos $(99,5 \%)$. O histopatológico foi normal em 1,5\% dos doadores. O teste de RIBA-2 e a pesquisa do RNA do VHC pelo PCR foram positivos em, respectivamente, 91,6 e 75\% dos doadores anti-HCV EIA-2 reagentes. A pesquisa do RNA do VHC foi positiva em $82 \%$ dos indivíduos RIBA-2 reagentes, em $37,5 \%$ dos doadores RIBA-2 indeterminados e em $9 \%$ dos RIBA-2 negativos. Hepatite crônica foi observada em $50 \%$ dos doadores RIBA-2 indeterminados. Entre 18 doadores com alterações mínimas, ao exame histopatológico, 11 (61\%) eram positivos para o RNA do VHC. Nossos doadores de sangue anti-HCV reagentes geralmente apresentam alterações clínicas, laboratoriais e histopatológicas próprias de pacientes com hepatites crônicas pelo VHC e uma elevada proporção destes podem ser identificados em entrevistas e avaliação médicas rotineiramente realizadas em bancos de sangue. Geralmente estes doadores infectados pelo VHC somente são identificados e bloqueados pelos resultados dos testes sorológicos.

\section{REFERENCES}

1. ALTER, H.J. - To C or not to C: these are the questions. Blood, 85: 1681-1695, 1995.

2. ALTER, H.J.; CONRY-CANTILENA, C.; MELPOLDER, J. et al. - Hepatitis C in asymptomatic blood donors. Hepatology, 26(suppl. 1): 29S-33S, 1997.

3. ALTER, H.J.; PURCELL, R.H.; SHIH, J.W. et al. - Detection of antibodies to hepatitis C virus in prospectively followed transfusion recipients with acute and chronic non-A, non-B hepatitis. New Engl. J. Med., 321: 1494-1500, 1989.

4. ALTER, H.J.; TEGTMEIER, G.; JETT, B. et al. - The use of a recombinant immunoblot assay in the interpretation of anti-hepatitis $\mathrm{C}$ virus reactivity among prospectively followed patients, implicated donors, and random donors. Transfusion, 31: 771776, 1991.

5. ALTER, M.J. - Epidemiology of hepatitis C in the West. Semin. Liver Dis., 15: 5-14, 1995.
6. AREIAS, J.; PEDROTO, I.; FREITAS, T. et al. - Hepatitis C virus carriers with normal ALT activity: viraemia, genotype and effect of interferon therapy. Gastroenterology, 110: A1143, 1996.

7. CHOO, Q.L.; KUO, G.; WEINER, A.J. et al. - Isolation of a cDNA clone derived from a blood-borne non-A, non-B viral hepatitis genome. Science, 244: 359-362, 1989.

8. CONRY-CANTILENA, C.; VAN RADEN, M.; GIBBLE, J. et al. - Routes of infection, viremia, and liver disease in blood donors found to have hepatitis $\mathrm{C}$ infection. New Engl. J. Med., 334: 1691-1696, 1996.

9. ESTEBAN, J.I.; ESTEBAN, R.; VILADOMIU, L. et al. - Hepatitis C virus antibodies among risk groups in Spain. Lancet, 2: 294-297, 1989.

10. ESTEBAN, J.I.; GONZALES, A.; HERNANDEZ, J.M. et al. - Evaluation of antibodies to hepatitis $\mathrm{C}$ virus in a contemporary study of transfusion-associated hepatitis. New Engl. J. Med., 323: 1107-1112, 1990.

11. GARCIA-SAMANIEGO, J.; ENRIQUEZ, A.; SORIANO, V. et al. - Third-generation recombinant immunoblot assay to confirm hepatitis $C$ virus-indeterminate serological samples. Vox Sang. (Basel), 64: 191-192, 1993

12. HOOFNAGLE, J.H. - Hepatitis C: the clinical spectrum of disease. Hepatology, 26(suppl.1): 15S-20S, 1997

13. KLEINMAN, S.; ALTER, H.; BUSCH, M. et al. - Increased detection of hepatitis C virus (HCV)-infected blood donors by a multiple-antigen $\mathrm{HCV}$ enzyme immunoassay. Transfusion, 32: 805-813, 1992.

14. KUO, G.; CHOO, Q.L.; ALTER, H.J. et al. - An assay for circulating antibodies to a major etiologic virus of human non-A, non-B hepatitis. Science, 244: 362-364, 1989.

15. LOK, A.S.F. \& GUNARATNAM, N.T. - Diagnosis of hepatitis C. Hepatology, 26(suppl.1): 48S-56S, 1997

16. PRATI, D.; CAPELLI, C.; ZANELLA, A. et al. - Influence of different hepatitis C virus genotypes on the course of asymptomatic hepatitis $\mathrm{C}$ virus infection. Gastroenterology, 100: 178-183, 1996.

17. PRIETO, M.; OLASO, V.; VERDU, C. et al. - Does the healthy hepatitis C virus carrier state really exist? An analysis using polymerase chain reaction. Hepatology, 22: 413-417, 1995.

18. PRINCE, A.M.; BROTMAN, B.; INCHAUSPE, G. et al. - Patterns and prevalence of hepatitis $\mathrm{C}$ virus infection in posttransfusion non-A, non-B hepatitis. J. infect.Dis, 167: 1296-1301, 1993.

19. ROSSINI, A.; GAZZOLA, G.B.; RAVAGGI, A. et al. - Long-term follow-up and infectivity in blood donors with hepatitis $\mathrm{C}$ antibodies and persistently normal alanine aminotransferase levels. Transfusion, 35: 108-111, 1995.

20. SALMERON, F.J.; PALACIOS, A.; PEREZ-RUIZ, M. et al. - Epidemiology, serological markers, and hepatic disease of anti-HCV ELISA-2 positive blood donors. Dig. Dis. Sci., 41: 1933-1938, 1996.

21. SCHIFF, E.R. - Hepatitis C and alcohol. Hepatology, 26(suppl. 1): 39S-42S, 1997.

22. SERFATY, L.; NOUSBAUM, J.R.; ELGHOUZZI, M.H. et al. - Prevalence, severity, and risk factors of liver disease in blood donors positive in a second-generation antihepatitis C virus screening test. Hepatology, 21: 725-729, 1995.

23. SHAKIL, A.O.; CONRY-CANTILENA, C.; ALTER, H.J. et al. - Volunteer blood donors with antibody to hepatitis $\mathrm{C}$ virus: clinical, biochemical, virologic and histologic features. Ann. intern. Med., 123: 330-337, 1995.

24. SHARARA, A.I.; HUNT, C.M. \& HAMILTON, J.D. - Hepatitis C. Ann. intern. Med., 125: 658-668, 1996.

25. ULRICH, P.; ROMEO, J.; LANE, P. et al. - Detection, semiquantitation, and genetic variation in hepatitis $\mathrm{C}$ virus sequences amplified from the plasma of blood donors with elevated alanine aminotransferase. J. clin. Invest., 86: 1609-1614, 1990.

Received: 01 December 1999

Accepted: 21 April 2000 